\title{
Seroepidemiologi toksoplasmosis pada masyarakat di Desa Rumengkor Dua Kabupaten Minahasa
}

\author{
${ }^{1}$ Bella Lestari \\ ${ }^{2}$ Billy J. Kepel \\ ${ }^{2}$ Fona Budiarso \\ 1 \\ Kandidat Skripsi Fakultas Kedokteran Universitas Sam Ratulangi Manado \\ ${ }^{2}$ Fakultas Kedokteran Universitas Sam Ratulangi Manado \\ email: bellalestari12016@gmail.com
}

\begin{abstract}
Toxoplasmosis is infectious disease caused by Toxoplasma gondii, which its definitive host is cat. Toxoplasmosis symptoms are asymptomatic but able to causing fatality particularly in pregnant woman which inducing miscarriage. This study aims to obtain Toxoplasmosis seroepidemiology among people of Rumengkor Dua Village Minahasa County by using Agglutination Latex Test (LAT Toxocheck-MT Eiken, Japan). This study method is cross-sectional descriptive . The population is people of Rumengkor Dua Village. The sample is blood serum collected from people of Rumengkor Dua Village. Data from interview questionnaire and latex agglutination test results included in the frequency distribution table and analyzed based on the results presentation. The result showed of toxoplasmosis seroepidemiology among people of Rumengkor Dua village Minahasa County by using Agglutination Latex Test (LAT Toxocheck-MT Eiken, Japan) is 68,2\%, with majority of women, age 41-50, junior high school as the last education, housewives, income less than 1 million rupiah, consuming raw meat, not consuming raw vegetables, wash vegetables and fruits, having cat and dog as pet, and have no miscarriage history.
\end{abstract}

Keywords: toxoplasmosis, cat

\begin{abstract}
Abstrak: Toksoplasmosis adalah penyakit infeksi yang disebabkan oleh toxoplasma gondii, dimana kucing adalah hospes definitifnya. Gejala toksoplasmosis asimptomatis namun akibat yang ditimbulkan bisa fatal terutama bila mengenai ibu hamil dan bisa mengakibatkan keguguran. Penelitian ini bertujuan untuk mengetahui seroepidemiologi toksoplasmosis pada masyarakat di Desa Rumengkor Dua Kabupaten Minahasa dengan menggunakan uji Aglutinasi Lateks (LAT Toxocheck-MT Eiken, Japan). Jenis penelitian ini merupakan penelitian deskriptif cross-sectional. Populasi penelitian ini adalah semua orang yang berada di desa Rumengkor Dua dengan sampel penelitian serum darah pada masyarakat di desa Rumengkor Dua. Data yang diperoleh dari wawancara langsung dengan subjek penelitian dan data hasil pemerikasaan laboratorium toksoplasmosis dengan cara tes aglutinasi lateks dimasukkan dalam tabel distribusi frekuensi dan dianalisa berdasarkan prosentasinya. Penelitian ini menunjukkan seroepidemiologi toksoplasmosis di Desa Rumengkor Dua Kabupaten Minahasa dengan menggunakan uji aglutinasi lateks (LAT Toxocheck-MT Eiken, Japan) adalah 68,2\%, yang mayoritas adalah wanita, usia 41-50 tahun, tingkat pendidikan SLTP, ibu rumah tangga, penghasilan $\leq 1$ juta rupiah, mengkonsumsi daging mentah atau kurang matang, tidak mengkonsumsi sayuran mentah, mencuci sayuran dan buah sebelum dikonsumsi, memelihara kucing, anjing, dan tidak ada riwayat keguguran.
\end{abstract}

Kata kunci: toksoplasmosis, kucing 
Penyakit infeksi merupakan penyebab 33\% kematian di seluruh dunia dan mengakibatkan penderitaan besar baik secara fisik, ekonomi maupun sosial. $^{1}$ Walau beberapa penyakit infeksi sudah terkontrol dengan bantuan teknologi modern, namun sisanya terus membahayakan setiap manusia. ${ }^{1,2}$ Mayoritas penyakit infeksi yang menyerang manusia adalah zoonosis dan sekitar 70\% merupakan emerging disease. ${ }^{1}$ Salah satu contohnya ialah toksoplasmosis.

Toksoplasmosis adalah penyakit yang disebabkan oleh Toxoplasma gondii, parasite protozoa yang merupakan salah satu parasit tersering pada manusia. ${ }^{3}$ Hampir sepertiga populasi manusia diperkirakan terinfeksi $T$ gondii. ${ }^{4}$ Toksoplasmosis dianggap menjadi penyebab kematian tersering akibat penyakit yang ditularkan melalui makanan di Amerika Serikat. Lebih dari 60 juta pria, wanita, dan anak-anak di AS terinfeksi $T$ gondii tapi hanya beberapa yang menunjukan gejala. Toksoplasmosis juga termasuk salah satu dari lima Infeksi Parasit Terabaikan (Neglected Parasisic Infection). ${ }^{5}$ Padahal akibat yang bisa ditimbulkan bisa fatal terutama bila mengenai ibu hamil, diantaranya adalah keguguran atau mengakibatkan bayi lahir dengan hidrosefalus, retinokoroiditis, kalsifikasi intrakranial, bahkan retardasi mental. ${ }^{6}$ Toksoplasmosis tidak ditularkan dari orang ke orang, kecuali dalam kasus transmisi dari ibu-ke-janin (kongenital) dan transfusi darah atau transplantasi organ. Manusia biasanya terinfeksi melalui tiga rute utama penularan yakni melalui makanan (foodborne), dari hewan ke manusia (zoonosis), dan dari ibu ke janin (transplasental). ${ }^{5}$

Kucing merupakan hospes definitif $\mathrm{T}$. gondii, dan hospes perantaranya adalah manusia, mamalia lain, dan burung. $T$. gondii ditemukan kosmopolit pada manusia dan binatang. ${ }^{7}$ Angka kejadian Toksoplasmosis biasanya tertinggi di daerah di dunia yang beriklim panas, lembab dan berada di dataran rendah. ${ }^{5,7,8}$ Peningkatan angka kejadian toksoplasmosis dilaporkan berkaitan dengan kemiskinan, tingkat pendidikan yang rendah, hidup di lingkungan ramai, keadaan sanitasi yang buruk, pekerjaan yang berhubungan dengan tanah atau daging, besarnya kemungkinan kontak dengan tanah serta mempunyai kucing atau anjing sebagai hewan peliharaan. ${ }^{5}$

Di Eropa Barat, Afrika, Amerika Selatan dan Tengah lebih dari 50\% dari wanita usia subur yang seropositif $\mathrm{T}$. gondii. ${ }^{9}$ Di Asia Tenggara seroprevalensi toksoplasmosis diperkirakan berkisar antara $<2-70 \%$. Di Indonesia sendiri prevalensi seropositif pada tahun 1964-1980 berkisar antara 2-63\%, tahun 1981-1994 berkisar antara 3,1-60\%, dan tahun 1995-2003 berkisar antara $58-80 \% .{ }^{10}$ Prevalensinya pada kucing dan anjing adalah 35-73\% dan 75\%. Pada tahun 1988 di Manado, Kapojos melakukan penelitian pada 108 orang pada usia 0-58 tahun dan menemukan 60\% seropositif T. gondii. ${ }^{11}$

Berdasarkan latar belakang di atas dan minimnya data epidemiologis mengenai toksoplasmosis, maka peneliti tertarik untuk melakukan penelitian tentang seroepidemiologi toksoplasmosis pada masyarakat di Desa Rumengkor Dua Kabupaten Minahasa.

Tujuan penelitian ini adalah untuk mengetahui bagaimana seroepidemiologi toksoplasmosis pada masyarakat di Desa Rumengkor Dua Kabupaten Minahasa dengan menggunakan uji Aglutinasi Lateks (LAT Toxocheck-MT Eiken, Japan).

\section{METODE PENELITIAN}

Penelitian ini dilakukan pada bulan Oktober 2015-Januari 2016 di Desa Rumengkor Dua Kecamatan Tombulu Kabupaten Minahasa dan di Laboratorium Parasitologi Fakultas Kedokteran Universitas Sam Ratulangi dengan menggunakan metode deskriptif crosssectional. P Populasi penelitian ini adalah semua orang yang berada di desa Rumengkor Dua Kabupaten Minahasa. Sampel yang diambil dalam penelitian ini adalah serum darah pada masyarakat di desa Rumengkor Dua Kabupaten 
Minahasa. Pengambilan sampel dengan mengambil serum darah pada masyarakat di desa Rumengkor Dua Kabupaten Minahasa. Sampel spesimen darah diperiksa di Laboratorim Parasitologi Fakultas Kedokteran Universitas Sam Ratulangi untuk dinilai postif atau tidaknya suatu sampel terhadap toksoplasmosis

\section{Tes Aglutinasi Lateks}

Tes aglutinasi latek menggunakan LAT Toxocheck-MT (Eiken, Japan). Prosedur pengujian dilakukan dengan mengikuti prosedur yang telah ditetapkan produsennya. Sampel darah disentrifus untuk mendapatkan serum plasma darah. Kemudian serum diencerkan dengan larutan buffer dengan perbandingan 1:64. (1 $\mu \mathrm{L}$ serum $+63 \mu \mathrm{L}$ buffer). Kemudian larutan yang sudah tercampur ini dimasukkan ke dalam U-bottom plate masing-masing $25 \mu \mathrm{L}$ dan tambahkan larutan lateks sebanyak $25 \mu \mathrm{L}$. Campur dan didiamkan pada suhu ruang selama 24 jam. Reaksi positif apabila terjadi aglutinasi latek seperti butiran pasir, sehingga sampel dapat dinyatakan seropositif toksoplasmosis. Adapun jika tidak terjadi aglutinasi maka sampel dinyatakan seronegatif toksoplasmosis.

\section{HASIL PENELITIAN}

Desa Rumengkor Dua adalah salah satu desa di Kecamatan Tombulu, Kabupaten Minahasa, Provinsi Sulawesi Utara, Indonesia. Secara geografis terletak di ketinggian 480 - 450 meter di atas permukaan laut. Wilayah administrasi pemerintahan Desa Rumengkor Dua terdiri atas 5 jaga, dengan jumlah penduduk sekitar 600 jiwa. Penduduk mayoritas bersuku minahasa

Tabel 1. Angka Kejadian Toksoplasmosis pada Masyarakat di Desa Rumengkor Dua Kabupaten Minahasa

\begin{tabular}{lrr}
\hline Toksoplasmosis & Frekuensi & $(\%)$ \\
\hline Positif & 15 & 68,2 \\
Negatif & 7 & 31,8 \\
Jumlah & 22 & 100,0 \\
\hline
\end{tabular}

\section{BAHASAN}

Hasil penelitian menunjukkan bahwa angka kejadian toksoplasmosis pada masyarakat desa Rumengkor Dua Kabupaten Minahasa adalah sebesar 68,2\%. Angka ini tidak banyak berbeda dengan penelitian yang dilakukan di Manado $^{11}$ (60\%), Daerah Istimewa Yogyakarta $^{12} \quad(61,5), \quad$ Jawa Tengah $^{12}$ $(62,54 \%)$ serta Tocantins, Brazil ${ }^{13}$ (68,37\%). Namun hasil ini jauh lebih tinggi dibandingkan dengan penelitian di Slovakia $^{14}$ (24,2\%), Amerika Serikat ${ }^{15}$ (22,5\%). Perbandingan variasi prevalensi di berbagai tempat ini perlu memperhatikan perbedaan populasi, banyaknya sampel maupun sensitivitas dan spesifitas metode yang digunakan.

Pada kelompok seropositif toksoplasmosis mayoritas adalah wanita (59,1\%). Wanita lebih sering terkena efek yang merugikan akibat toksoplasmosis walau ternyata jenis kelamin tidak berhubungan dengan prevalensi toksoplasmosis. ${ }^{16}$

Rerata umur responden penelitian adalah 55 tahun, dengan umur tertua 85 tahun sedangkan umur termuda adalah 28 tahun. Kelompok usia terbanyak pada kelompok seropositif toksoplasmosis adalah usia 41-50 (27,3\%) Toksoplasmosis dapat menyerang siapa saja tanpa memandang usia. ${ }^{5}$ Namun di Eropa, Sudan, Meksiko, dan Brazil prevalensinya meningkat seiring dengan usia. Sedangkan di Tanzania dan Amerika Serikat, toksoplasmosis tertinggi ditemukan pada usia 12-25 tahun dan 15-44.

Dari 15 orang dengan seropositif toksoplasmosis didapatkan distribusi pendidikan dari yang paling banyak sampai sedikit berturut-turut adalah SLTP 6 orang (27,3\%), SLTA 5 orang (22,7\%), SD 3 orang (13,6\%) dan S1 1 orang (4,5\%).

Penelitian yang dilakukan di Iran menemukan bahwa pendidikan yang rendah berhubungan dengan meningkatnya kejadian toksoplasmosis. ${ }^{17}$ 
Lestari, Kepel, Budiarso: Seroepidemiologi toksoplasmosis pada...

Tabel 2. Distribusi Toksoplasmosis Berdasarkan Karakteristik Faktor Resiko

\begin{tabular}{|c|c|c|c|c|c|c|}
\hline \multirow{2}{*}{ Karakteristik } & \multicolumn{4}{|c|}{ Toksoplasmosis } & \multirow{2}{*}{ Total } & \multirow{2}{*}{$\%$} \\
\hline & Positif & $\%$ & Negatif & $\%$ & & \\
\hline \multicolumn{7}{|l|}{ Usia: } \\
\hline$<41$ & 1 & 4,5 & 1 & 4,5 & 1 & 9,1 \\
\hline $41-50$ & 6 & 27,3 & 2 & 9,1 & 8 & 36,4 \\
\hline $51-60$ & 3 & 13,6 & 2 & 9,1 & 5 & 22,7 \\
\hline$>60$ & 5 & 22,7 & 2 & 9,1 & 7 & 31,8 \\
\hline \multicolumn{7}{|l|}{ Jenis Kelamin: } \\
\hline Wanita & 13 & 59,1 & 6 & 27,3 & 19 & 86,4 \\
\hline Laki-laki & 2 & 9,1 & 1 & 4,5 & 2 & 13,6 \\
\hline \multicolumn{7}{|l|}{ Tingkat Pendidikan: } \\
\hline SD & 3 & 13,6 & 2 & 9,1 & 5 & 22,7 \\
\hline SLTP & 6 & 27,3 & 2 & 9,1 & 8 & 36,4 \\
\hline SLTA & 5 & 22,7 & 3 & 13,6 & 8 & 36,4 \\
\hline S1 & 1 & 4,5 & 0 & 0,0 & 1 & 4,5 \\
\hline \multicolumn{7}{|l|}{ Pekerjaan: } \\
\hline IRT & 9 & 40,9 & 6 & 27,3 & 15 & 68,2 \\
\hline Petani & 2 & 9,1 & 1 & 4,5 & 3 & 13,6 \\
\hline Pensiunan & 1 & 4,5 & 0 & 0,0 & 1 & 4,5 \\
\hline Swasta & 1 & 4,5 & 0 & 0,0 & 1 & 4,5 \\
\hline PNS & 2 & 9,1 & 0 & 0,0 & 2 & 9,1 \\
\hline \multicolumn{7}{|l|}{ Penghasilan: } \\
\hline$\leq 1.000 .000$ & 7 & 31,8 & 3 & 13,6 & 10 & 45,4 \\
\hline $1.000 .001-2.000 .000$ & 5 & 22,7 & 3 & 13,6 & 8 & 36,3 \\
\hline $2.000 .001-3.000 .000$ & 1 & 4,5 & 1 & 4,5 & 2 & 9,1 \\
\hline$>3.000 .000$ & 2 & 9,1 & 0 & 0,0 & 2 & 9,1 \\
\hline \multicolumn{7}{|c|}{ Konsumsi daging mentah atau kurang matang: } \\
\hline Ya & 13 & 59,1 & 7 & 31,8 & 20 & 90,9 \\
\hline Tidak & 2 & 9,1 & 0 & 0,0 & 2 & 9,1 \\
\hline \multicolumn{7}{|l|}{ Konsumsi sayuran mentah: } \\
\hline Ya & 6 & 27,3 & 3 & 13,6 & 9 & 40,9 \\
\hline Tidak & 9 & 40,9 & 4 & 18,2 & 13 & 59,1 \\
\hline \multicolumn{7}{|c|}{ Mencuci sayuran dan buah dikonsumsi: } \\
\hline Ya & 13 & 59,1 & 7 & 31,8 & 20 & 90,9 \\
\hline Tidak & 2 & 9,1 & 0 & 0,0 & 2 & 9,1 \\
\hline \multicolumn{7}{|l|}{ Memelihara Kucing: } \\
\hline Ya & 8 & 36,4 & 3 & 13,6 & 11 & 50,0 \\
\hline Tidak & 7 & 31,8 & 4 & 18,2 & 11 & 50,0 \\
\hline \multicolumn{7}{|l|}{ Memelihara Anjing: } \\
\hline Ya & 10 & 45,5 & 6 & 27,3 & 16 & 72,7 \\
\hline Tidak & 5 & 22,7 & 1 & 4,5 & 6 & 27,3 \\
\hline \multicolumn{7}{|l|}{ Riwayat Keguguran: } \\
\hline Pernah & 1 & 5,3 & 0 & 0,0 & 1 & 5,3 \\
\hline Tidak Pernah & 12 & 63,2 & 6 & 31,6 & 18 & 94,7 \\
\hline
\end{tabular}

Hasil penelitian ini menunjukkan kelompok seropositif toksoplasmosis 40,9\% adalah ibu rumah tangga. Pekerjaan yang berhubungan dengan daging atau tanah merupakan salah satu faktor resiko toksoplasmosis. ${ }^{18}$ Hal ini memungkinkan individu tersebut menelan daging mentah bahkan tanah secara tak sengaja. ${ }^{5}$ Memasak merupakan salah satu kegitan yang memungkinkan ibu rumah tangga secara 
tidak sengaja menelan daging mentah yang mengandung ookista saat akan mengolahnya.

Penelitian ini menunjukkan 86,7\% responden seropositif toksoplasmosis mengkonsumsi daging mentah atau kurang matang. Mengkonsumsi daging mentah ata kurang matang juga merupakan salah satu faktor resiko toksoplasmosis. ${ }^{19}$ Masyarakat desa Rumengkor Dua memang terbiasa untuk mengkonsumsi ragey yaitu sate babi dengan ukuran potongan yang besar dan memungkinkan bagian tengah daging tidak masak dengan sempurna. Bagian ini memungkinkan bradizoit masih hidup dan menularkannya pada manusia.

Berdasarkan hasil penelitian ini responden yang seropositif toksoplasmosis yang tidak mengkonsumsi sayuran mentah ada 9 orang (60\%). Sayuran yang tercemar ookista dari tanah, dapat menyebabkan toksoplasmosis apabila pencucian sayuran yang dikonsumsi mentah ini kurang baik. ${ }^{20}$ Terlebih jika sayuran atau buah tidak dicuci sebelum dikonsumsi. Penelitian ini menunjukkan responden yang seropositif toksoplasmosis $86,7 \%$ mencuci sayuran dan buah sebelum dikonsumsi

Kucing mempunyai peranan yang sangat penting dalam penyebaran toksoplasmosis sebagai hospes definitif dan dapat mengeluarkan jutaan ookista dari fesesnya serta mengkontaminasi air dan tanah di sekelilingnya. ${ }^{4}$ Hal ini memudahkan manusia yang memelihara kucing untuk terkena toksoplasmosis. ${ }^{21}$ Hasil penelitian ini menunjukkan responden seropositif toksoplasmosis 53,3\% memelihara kucing.

Walaupun anjing bukan merupakan hospes definitif toksoplasmosis namun anjing merupakan salah satu hospes perantaranya. ${ }^{4}$ Pemeliharaan anjing juga berkaitan dengan toksoplasmosis. ${ }^{22}$ Pada tabel 2 dapat dilihat bahwa responden yang seropositif toksoplasmosis $\quad 66,7 \%$ memelihara anjing.

Dari 13 wanita yang seropositive toksoplasmosis, 1 orang $(7,7 \%)$ pernah keguguran dan sisanya $\mathbf{( 9 2 , 3 \% )}$ tidak pernah keguguran. Penelitian lain menunjukkan ada hubungan antara riwayat keguguran dan infeksi toksoplasmosis karena infeksi primer toksoplamosis selama kehamilan dapat menyebabkan keguguran. $^{23}$

\section{SIMPULAN}

Berdasarkan hasil penelitian dapat disimpulkan bahwa angka kejadian toksoplasmosis pada masyarakat desa Rumengkor Dua Kabupaten Minahasa dengan menggunakan uji Aglutinasi Lateks (LAT Toxocheck-MT Eiken, Japan) adalah sebesar 68,2\%. Angka kejadian seropositif toksoplasmosis tertinggi pada wanita (59,1\%), golongan usia 41-50 tahun (27,3\%), tingkat pendidikan SLTP $(27,3 \%)$, pekerjaan ibu rumah tangga (40,9\%), penghasilan $\leq 1$ juta rupiah $(31,8 \%)$, mengkonsumsi daging mentah atau kurang matang (59,1\%), tidak mengkonsumsi sayuran mentah (40,9\%), mencuci sayuran dan buah sebelum dikonsumsi (59,1\%), memelihara kucing (36,4\%), anjing (45,5\%), dan tidak ada riwayat keguguran (63,2\%).

\section{SARAN}

Bagi peneliti selanjutnya diharapkan dapat melakukan penelitian dengan jumlah sampel yang lebih besar dan menggunakan kuesioner yang lebih baik serta dapat menganalisa hubungan faktor-faktor resiko dengan kejadian toksoplasmosis

\section{DAFTAR PUSTAKA}

1. Muhie Y, Keskes S. Toxoplasmosis: Emerging and Reemerging Zoonosis. Afr. J. App. Microbiol. Res. 2014;3(1):1-11

2. Cdc.gov [internet]. Infectious Disease Information. 2007 Oct 1 [cited 2015 Sept 17]. Avaible from: http://www.cdc.gov/ncidod/diseases/e id/

3. Hill D, Dubey JP. Toxoplasma gondii: transmission, diagnosis and prevention. Clin Microbiol Infect. 2002 Oct;8(10):634-40

4. Dalimi A, Abdoli A. Latent Toxoplasmosis and Human. Iran J Parasitol. 2012; 7(1): 1-17. 
5. Centre for Disease Control and Prevention. 2013 Jan 10. [cited 2015 Sept 17] available from: http://www.cdc.gov/parasites/toxopla smosis/

6. Tenter AM, Heckeroth AR, Weiss LM. Toxoplasma gondii: from animals to humans. Int J Parasitol. 2000 Nov; 30(12-13):1217-58

7. Lisawati S, Gandahusada S. Toxoplasma gondii. Dalam: Inge S, Is SI, Pudji KS, Saleha S. Buku Ajar Parasitologi Kedokteran. Edisi ke-3. Jakarta: FKUI; 2013. hal.162

8. Wahyuni S. Toxoplasmosis dalam Kehamilan. 2013 Mei 31 [cited 2015 Sept 17]. Available from http://download.portalgaruda.org/artic le.php?article $=127841 \& \mathrm{val}=4897$

9. Prasad KJ. Emerging and Reemerging Parasite Disease. JIMSA. 2010;23(1):46

10.Veraanoot $\mathbf{N}$, Ling LY, Yik FM. Toxoplasma gondii: The Parasite in Trend. In: Yvonne ALL and Indra V, editors. Parasites and Their Vectors: A Special Focus on South East Asia. Wien: Springer; 2013:p. 155.

11.Gandahusada S. Study on The Prevalence of Toxoplasmosis In Indonesia: A Review. 1991 [cited 2015 Sept 17]. Available from: http://www.tm.mahidol.ac.th/seameo/ 1991-22-suppl/21-93-98.pdf

12.Artama WT, Retmanasari A, Widartono BS, Wijayanti M, Sujono. Pemetaan penyakit zoonotik menggunakan sistem informasi geografis (sig) dengan pendekatan one health. Prosiding Seminar Ilmiah PBBMI. Yogyakarta: Bagian Kimia FK UGM; 2015: 1-10

13.Marcos GS, Marina CV, Ana MC. Prevalence of toxoplasmosis in pregnant women and vertical transmission of Toxoplasma gondii in patients from basic units of health from Gurupi, Tocantins, Brazil, from 2012 to 2014. PLoS One. 2015; 10(11): e0141700

14.Studenicova C, Bencaiova G, Holkova R. Seroprevalence of Toxoplasma gondii antibodies in a healthy population from Slovakia. Eur J Intern Med. 2006;17:470-473
15.Jones JL, Kruszon-Moran D, Wilson M, McQuillan G, Navin T, McAuley JB. Toxoplasma gondii Infection in the United Stated: Seroprevalence and Risk Factor. Am. J. Epidemiol. 2001. 154(4):357-65

16.Chiang TY, Hsieh HH, Kuo MC, Chiu KT, Lin WC, Fan CK, et al. Seroepidemiology of Toxoplasma gondii Infection among Heakthy Blood Donors in Taiwan. PLoS One. 2012; 7(10): e48139

17.Abaie J, Amiri S, Mostafavi E, Hassan N, Lofti P, Rastaghi ARE, et al. Seroprevalence and Risk Factors for Toxoplasma gondii Infection among Pregnant Women in Northeast Iran. Clin Vaccine Immunol. 2013 Nov; 20(11): 1771-3

18.Jones JL, Dargelas V, Roberts J, Press C, Remington JS, Montoya JG. Risk Factors for Toxoplasma gondii Infection in the United States. Clin Infect Dis. 2009 Sep;49(6):878-84

19.Awoke K, Nibret E, Munshea A. Seroprevalence and associated risk factors of Toxoplasma gondii infection among pregnant women attending antenatal care at Felege Hiwot Referral Hospital, northwest Ethiopia. Asian Pac J Trop Med. 2015 Jul;8(7):549-54

20.Gebremedhin EZ, Abebe AH, Tessema TS, Tullu KD, Medhin G, Vitale M, et al. Seroepidemiology of Toxoplasma gondii infection in women of child-bearing age in central Ethiopia. BMC Infect Dis. 2013 Feb;13:101

21.Cong $\mathbf{W}$, Dong $X Y$, Meng QF, Zhou N, Wang XY, Huang SY, et al. Toxoplasma gondii Infection in Pregnant Women: A Seroprevalence and Case-Control Study in Eastern China. Biomed Res Int. 2015; 2015:170278

22.Sroka S, Bartelheimer $\mathrm{N}$, Winter $\mathrm{A}$, Heukelbach J, Ariza L, Ribeiro H, et al. Prevalence and risk factors of toxoplasmosis among pregnant women in Fortaleza, Northeastern Brazil. Am J Trop Med Hyg. 2010 Sep;83(3):528-33

23.Hernandez-Cortazar I, Acosta-Viana KY, Ortega-Pachelo A, Guzman_marin 
Jurnal e-Biomedik (eBm), Volume 4, Nomor 1, Januari-Juni 2016

ES, Aguilar-Caballero AJ, JimenezCoello M. Toxoplasmosis in Mexico:

and Animals. Rev Inst Med Trop Sao Epidemiological Situation in Humans

Paulo. 2015; 57(2):93-103 